\title{
WPW Induced Ventricular Tachycardia in a Patient Using Quetiapine
}

\author{
Ketiapin Kullanan Bir Hastada WPW Nedenli Ventriküler Taşikardi
}

\section{Adem Kaya}

Adana City Traning and Research Hospital, Emergency Medicine Clinic, Adana- TURKEY

\begin{abstract}
Ventricular tachycardia (VT) is a mortal rhythm that can occur for many reasons. Wolff Parkinson White (WPW) syndrome can cause VT. Although there are usually signs and symptoms specific to underlying diseases, sometimes it may not be possible to make a differential diagnosis. A 32-year-old male presented to the emergency department with complaints of sudden onset of palpitations and weakness. He was using quetiapine in history. His hemodynamic were stable and his rhythm on the electrocardiogram (ECG) was evaluated as VT. Medical cardioversion was started with amiodarone. Electrical cardioversion was performed after the development of nausea, dizziness, and chest pain symptoms, and a return to normal sinus rhythm was achieved. There were no typical findings in the control ECG showing WPW syndrome or the effect of Quetiapine. The diagnosis of WPW was confirmed by an electrophysiological study (EPS), and successful treatment was performed by catheter ablation. Early electrical cardioversion may be considered when there is no response to medical cardioversion in the acute treatment of VT. Earlier application of specific treatment procedures such as EPS may be considered for differential diagnosis and curative treatment.

$\ddot{O} Z \boldsymbol{E T}$

Ventriküler taşikardi (VT) birçok neden ile oluşabilen ölümcül bir ritimdir. Wolff Parkinson White (WPW) sendromu VT'ye neden olabilmektedir. Genellikle altta yatan hastallklara spesifik belirti ve bulgular bulunsa da bazen ayırıcı tanı yapabilmek mümkün olmayabilir. Otuz iki yaşında erkek ani başlayan çarpıntı ve halsizlik şikâyeti ile acile başvurdu. Öyküde ketiapin kullandı̆̆ı ögrenildi. Fizik bakıda hemodinamisi stabil ve elektrokardiyogramındaki (EKG) ritim VT olarak değerlendirildi. Amiodaron ile medikal kardiyoversiyona başlandi. Takiplerinde bulantı, baş dönmesi ve göğüs ağrısı semptomlarının gelişmesi sonucunda elektriksel kardiyoversiyon uygulanarak normal sinüs ritmine dönüş sağland. Kontrol EKG sinde WPW sendromunu ya da Ketiapin etkisini gösteren tipik bulgular mevcut değildi. Elektrofizyolojik çalışma (EPS) ile WPW tanısı kesinleştirilen hastaya kateter ablasyonu ile başarılı tedavi uygulandl. Ventriküler taşikardi için uygulanan akut medikal tedavi protokollerine yanıt allnamadığı durumlarda elektriksel kardiyoversiyon ön planda düşünülebilir. Ayırıcı tanı ve küratif tedavi için EPS gibi spesifik tedavi prosedürlerinin daha erken uygulanması göz önünde bulundurulabilir.
\end{abstract}

Keywords:

Electrophysiological study Ouetiapine, Catheter ablation Ventricular Tachycardia, Wolff Parkinson White

\section{Anahtar Kelimeler:} Elektrofizyolojik çalışma Ketiapin Kateter ablasyonu Ventriküler Taşikardi Wolff Parkinson White

\section{INTRODUCTION}

Ventricular tachycardia (VT) is a mortal cardiac dysrhythmia that requires emergency treatment. It can occur for many reasons such as cardiac ischemia, metabolic disorders, electrolyte abnormalities, drugs, toxins, infections, and cardiac conduction disorders (13 ). The most cause of VT is ischemic heart disease $(4,5)$. Generally, acute treatment is performed with medical or electrical cardioversion, but curative treatment should be directed to the underlying cause $(5,6)$. Many drugs used for treatment can cause cardiac conduction disturbances (they often cause QT prolongation) and cause fatal dysrhythmias. Quetiapine used by our patient can also cause VT $(7,8)$. Cardiac conduction disorders can cause fatal dysrhythmias such as VT, especially at young ages $(9,10)$. Wolff Parkinson White (WPW) syndrome is a conduction disorder that can cause VT (11). Determining the aetiology of fatal dysrhythmias such as ventricular tachycardia is important for successful treatment. Acute treatment procedures are generally similar. On the other hand, the order of priority of acute treatments (medical and electrical) that should be applied may vary depending on the etiological reason and the clinical condition of the patient (10).

In this case report, we presented a case who used quetiapine, applied to the emergency service with palpitations (VT), did not respond to standard medical therapy, normal sinus rhythm was achieved with electrical cardioversion, was diagnosed with WPW via EPS, and successfully treated with catheter ablation.

\section{CASE}

A 32-year-old male patient was admitted to the emergency department with sudden onset of palpitations and weakness. The patient's first ECG was evaluated as VT and his vitals were stable. It was learned in history that he used a single dose of quetiapine $400 \mathrm{mg}$ per day.

Correspondence: Adem Kaya, MD., Adana City Traning and Research Hospital, Emergency Medicine Clinic, 01130, Adana-

Turkey. E mail: drademkaya@gmail.com

Cite as: Kaya A. WPW Induced Ventricular Tachycardia in a Patient Using Quetiapine. Phnx Med J. 2021;3(2):91-94. 
Kaya et al.

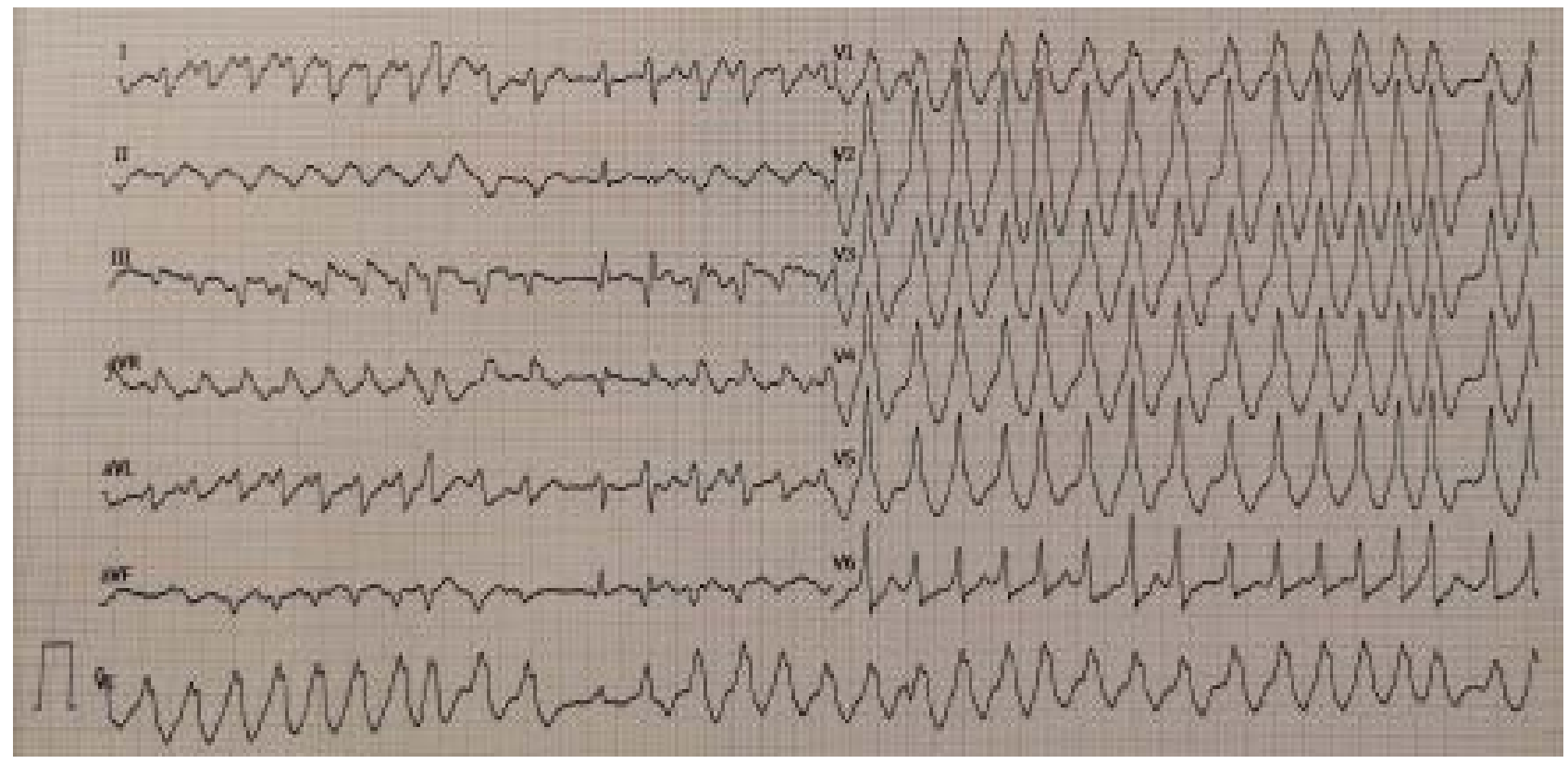

Figure 1: Electrocardiography of the patient at the time of admission

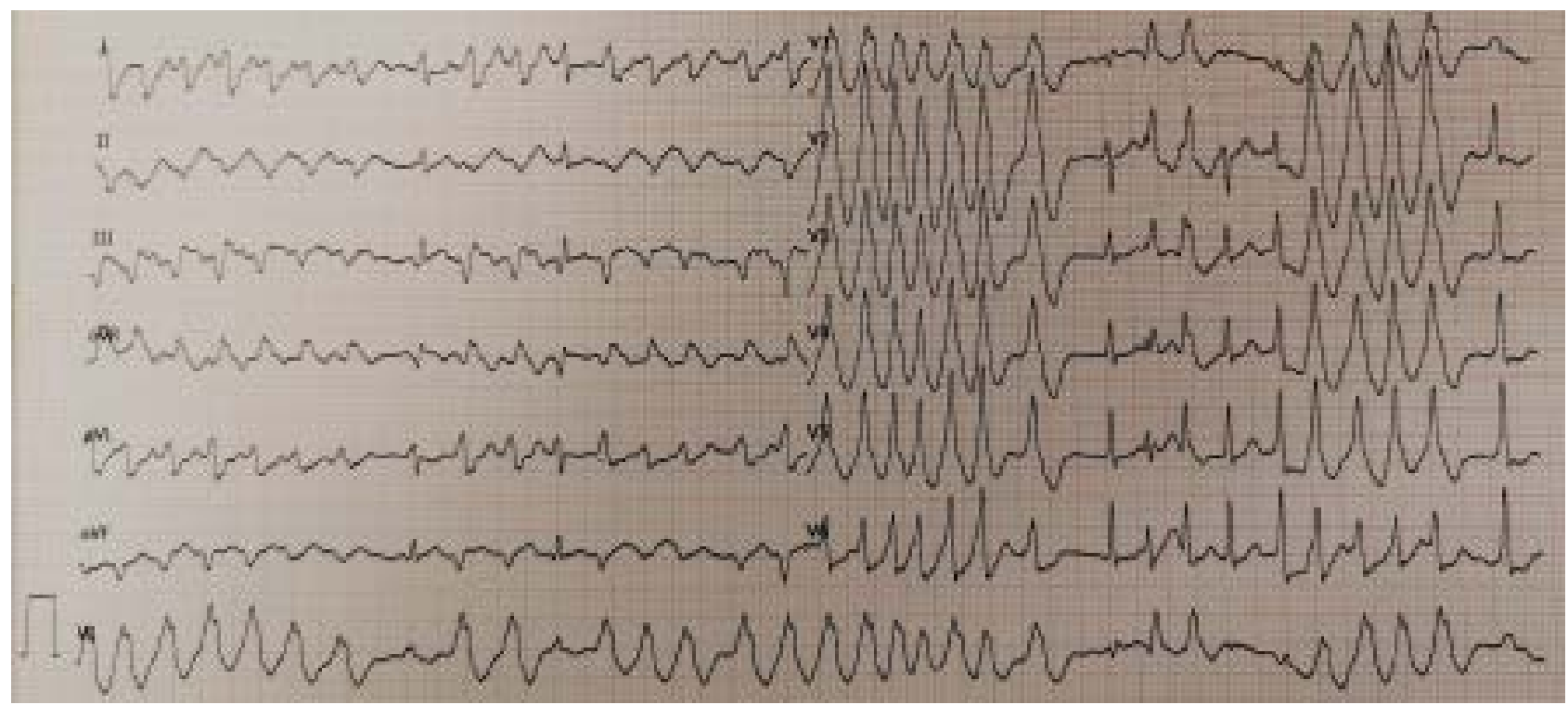

Figure 2: Control electrocardiography of the patient during the follow-up process.

The patient had no other medical history and was not a smoker. It was determined that the patient took his medication regularly and took the last dose 12-14 hours ago. The patient was monitored with a defibrillator in the emergency department, his vitals and 12-lead ECG were taken. The rhythm on the ECG was evaluated as a wide QRS complex tachycardia (VT) (Figure 1). The patient's Glasgow coma scale (GCS): 15 points, Tension: 110/70 $\mathrm{mmHg}$, pulse rate: 193/minute, SD: 16/ minute, $\mathrm{SpO} 2$ : $99 \%$, and fever $36.5{ }^{\circ} \mathrm{C}$ was determined. On physical examination, ventilation of the lungs was normal, and respiration was equally evaluated, also cardiovascular evaluation was evaluated as arrhythmic arrhythmic tachycardia, no additional sound, no murmur, and equally pulses. The patient's blood glucose: $113 \mathrm{mg} /$ $\mathrm{dL}, \mathrm{Na}+: 138 \mathrm{mmol} / \mathrm{L}, \mathrm{Cl}-101 \mathrm{mmol} / \mathrm{L}, \mathrm{K}+: 4.2 \mathrm{mmol} / \mathrm{L}$, $\mathrm{iCa}+1,3 \mathrm{mmol} / \mathrm{L}, \mathrm{pH}: 7.36, \mathrm{HCO} 3: 24 \mathrm{mEq} / \mathrm{L}, \mathrm{PCO} 2: 38$ $\mathrm{mmHg}$, and $\mathrm{SaO} 2: 98 \%$ was determined in the arterial blood gas analysis. In the emergency department, oral $300 \mathrm{mg}$ acetylsalicylic acid and intravenous (iv) $60 \mathrm{mg}$ enoxaparin were given, and medical cardioversion was started with $300 \mathrm{mg}$ Amiodarone (Amiodarone was the only agent accessible in the emergency department during this period). Afterward, on the ECHO performed by the cardiologist, there was no wall motion defect or valve problem, and the Ejection Fraction (EF) was evaluated as normal. Blood pressure: 100/70 $\mathrm{mmHg}$, heart rate: 197/ min, and clinical findings similar to the first examination were found in the follow-up of the patient. The rhythm in the second ECG was compatible with VT, and very frequent fusion and capture beats were observed (Figure 2). Secondarily, in addition to Amiodarone infusion (planned as $1 \mathrm{mg} / \mathrm{kg} /$ hour iv for the first 6 hours), 2-gram magnesium was administered intravenously. Follow-up blood pressure was 100/60 $\mathrm{mmHg}$ and pulse were 198/ min. When the symptoms of nausea, dizziness, and chest 


\section{Phnx Med J. July 2021, Volume 3 No 2}

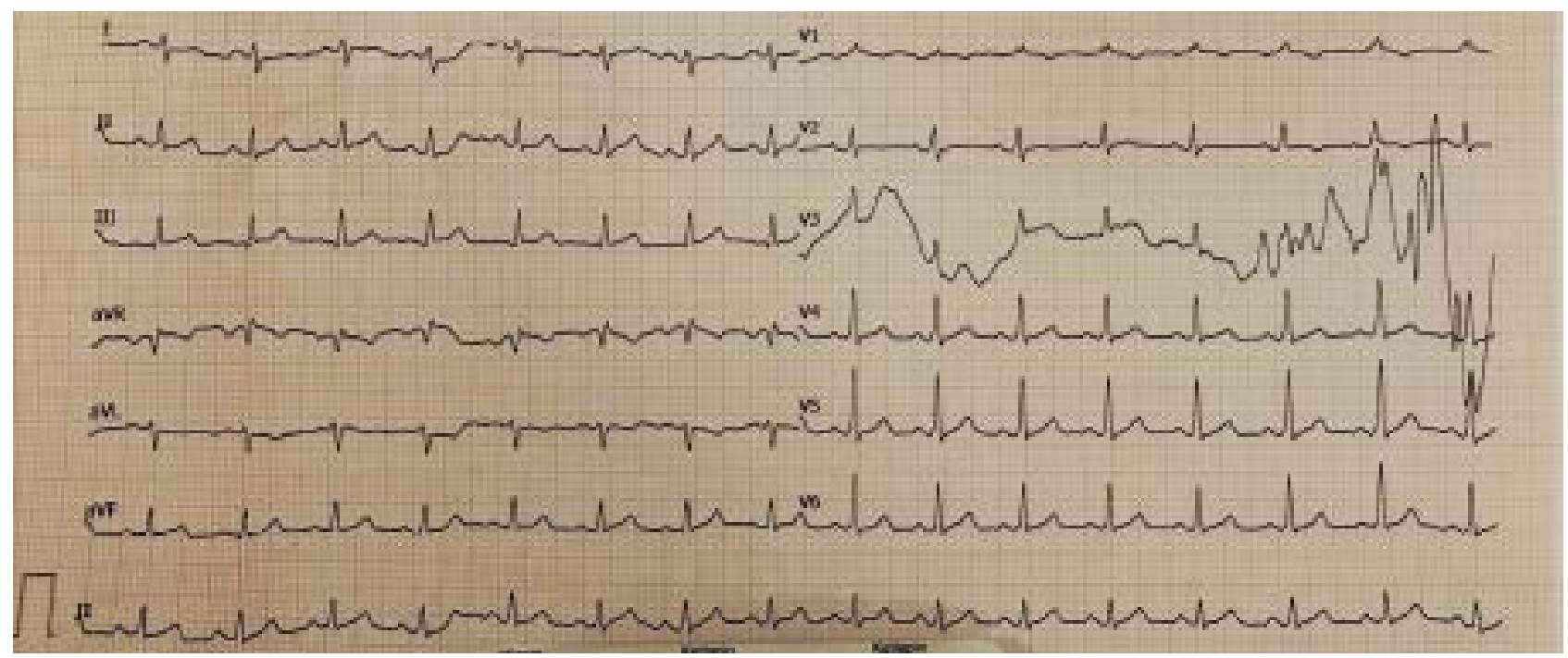

Figure 3: Electrocardiography of the patient after electrical cardioversion.

pain started one hour later, sedoanalgesia was applied with $2.5 \mathrm{mg}$ midazolam and $50 \mathrm{mg}$ fentanyl, then electrical cardioversion was performed with 100 joules, and return to sinus rhythm was achieved (Figure 3 ).

The patient's use of Quetiapine caused difficulties in the definitive diagnosis, but the absence of drug-related clinical signs and symptoms, and the last drug dose taken before 12 hours partially excluded this diagnosis. The last ECG was in sinus rhythm with a pulse rate $=$ of $96 / \mathrm{min}$, $\mathrm{PR}=14-16 \mathrm{~ms}, \mathrm{QRS}=80-100 \mathrm{~ms}$, and Qtc $=38 \mathrm{~ms}$. The presence of a delta wave-like slope at the beginning of the QRS wave in the precordial leads suggested WPW, but the absence of a clear delta wave appearance and the width of the QRS wave within normal limits made the diagnosis difficult (Figure 3). After excluding ischemic, metabolic, and infective causes, EPS was performed. Successful catheter ablation was performed after the definitive diagnosis of WPW was made in EPS. The patient was discharged without any complications.

\section{DISCUSSION}

Many conditions can cause ventricular tachycardias. The treatment for the underlying cause of VT is the main factor in providing a cure. However, life-saving interventions are a priority in acute treatment $(6,10)$. Patients who come to the emergency department with VT may present with normal vital signs or with global hypoperfusion findings or cardiac arrest $(2,10)$. The patient's clinic and ECG findings at the time of admission are the main factors that determine the treatment procedure to be administered $(5,10)$. Current studies report that the causes of ventricular tachycardia are often ischemic and structural cardiac pathologies $(3,4)$. On the other hand, drug-induced cardiac dysrhythmias should be carefully analyzed in patients with comorbidities and a history of drug use because many drugs can prolong the QT period and cause fatal dysrhythmias (8). Quetiapine used by our patient is an antipsychotic agent that is frequently used in psychiatry and can cause QT prolongation and VT (7). In the formation of fatal dysrhythmias due to antipsychotics, in addition to the prolongation of the QT duration, the duration (width) of the QRS wave and the height of the $\mathrm{R}$ 'wave in aVR may exceed $3 \mathrm{~mm}(8,12)$.
These findings were not present in the capture beats seen in the ECG of our patient and on the ECG in sinus rhythm. Therefore, the diagnosis of quetiapine-induced VT may not be considered in the foreground.

Cardiac conduction disorders may cause VT as another reason. Especially WPW syndrome can cause VT that can result in death (11). Considering the lack of response to medical cardioversion and existing ECG rhythms in the differential diagnosis (as in this case), cardiac ischemia, structural diseases, and conduction disorders may be considered.

Ventricular tachycardia treatment may differ according to the current diagnosis. Medical treatment with Procainamide, Flecainide, Ibutilide, Sotalol, and Amiodarone can be administered especially in patients with stable hemodynamic in the acute treatment of VT due to WPW syndrome. On the other hand, Procainamide, Flecainide, and Ibutilide are recommended in the presence of polymorphic VT such as Torsades de pointes. In cases where hemodynamic begin to deteriorate, such as chest pain and changes in consciousness, which indicate impaired organ perfusion, the primary treatment option is electrical cardioversion. In the chronic treatment of cardiac arrhythmias due to WPW syndrome (after achieving sinus rhythm in acute conditions), catheter ablation is a class-I recommendation, and Flecainide, Propafenone, Sotalol, and Amiodarone are defined as a class-IIa recommendation in medical treatment $(10,11)$. In the acute treatment of our case, medical cardioversion was initiated with iv Amiodarone, the only available agent that could be used in the emergency at that time. However, since there was no response to medical cardioversion, sinus rhythm was achieved with electrical cardioversion. Afterward, a diagnosis of WPW was made by performing EPS for differential diagnosis and treatment. Then, successful treatment was performed with catheter ablation. The patient was discharged without any complications.

Finally, evaluating patients presenting with VT as a whole with all their parameters and providing specific treatment for the cause may increase the success of curative treatment. 


\section{Kaya et al.}

\section{CONCLUSION}

Wolff Parkinson White syndrome can present with fatal rhythms such as VT. The presence of distracting factors such as medication use, and comorbidities and the absence of specific ECG findings can make differential diagnosis difficult. Performing specific treatment procedures for the underlying cause with careful evaluation can provide curative treatment. As a result, the most important factor that increases the diagnosis and treatment success may be the evaluation of the patient's history, physical examination, and clinical data as a whole.

Conflict of Interest: No conflict of interest was declared by the author.

\section{REFERENCES}

1. Almas A, Hameed K, Hameed A. Ventricular tachycardia: a hospital perspective. J Coll Physicians Surg Pak. 2005 Feb;15(2):68-70. PMID: 15730827.

2. Roberts-Thomson KC, Lau DH, Sanders P. The diagnosis and management of ventricular arrhythmias. Nat Rev Cardiol. 2011 Jun;8(6):311-321. doi: 10.1038/nrcardio.2011.15.

3. Brunckhorst C, Delacretaz E. Kammertachykardien--Atiologie, Mechanismen, Therapie [Ventricular tachycardia--etiology, mechanisms and therapy]. Ther Umsch. 2004 Apr;61(4):257-264. German. doi: 10.1024/0040-5930.61.4.257.

4. Lo R, Chia KK, Hsia HH. Ventricular Tachycardia in Ischemic Heart Disease. Card Electrophysiol Clin. 2017 Mar;9(1):25-46. doi: 10.1016/j. ccep.2016.10.013.

5. Saliba WI, Natale A. Ventricular tachycardia syndromes. Med Clin North Am. 2001 Mar;85(2):267-304. doi: 10.1016/s0025-7125(05)70316-3. PMID: 11233949

6. AlMahameed ST, Ziv O. Ventricular Arrhythmias. Med Clin North Am. 2019 Sep;103(5):881-895. doi: 10.1016/j.mcna.2019.05.008.

7. Hasnain M, Vieweg WV, Howland RH, Kogut C, Bireden Crouse EL, Koneru JN, et al. Quetiapine, QTc interval prolongation, and torsade de pointes: a review of case reports. Ther Adv Psychopharmacol. 2014;4(3):130-138. doi:10.1177/2045125313510194

8. De Hert M, Detraux J, van Winkel R, Yu W, Correll CU. Metabolic and cardiovascular adverse effects associated with antipsychotic drugs. Nat Rev Endocrinol. 2011 Oct 18;8(2):114-126. doi: 10.1038/nrendo.2011.156.

9. Mohan S, Balaji S. Management of asymptomatic ventricular preexcitation. Indian Pacing Electrophysiol J. 2019 Nov-Dec;19(6):232-239. doi: 10.1016/j.ipej.2019.10.001.

10. Priori SG, Blomström-Lundqvist C, Mazzanti A, Blom N, Borggrefe M, Camm J, et al. ESC Scientific Document Group, 2015 ESC Guidelines for the management of patients with ventricular arrhythmias and the prevention of sudden cardiac death: The Task Force for the Management of Patients with Ventricular Arrhythmias and the Prevention of Sudden Cardiac Death of the European Society of Cardiology (ESC), Endorsed by: Association for European Paediatric and Congenital Cardiology (AEPC), European Heart Journal, Volume 36, Issue 41, 1 November 2015, Pages 2793-2867, https://doi.org/10.1093/eurheartj/ehv316

11. Chhabra L, Goyal A, Benham MD. Wolff Parkinson White Syndrome. 2020 Aug 10. In: StatPearls [Internet]. Treasure Island (FL): StatPearls Publishing; 2020 Jan-. PMID: 32119324.

12. Tan HH, Hoppe J, Heard K. A systematic review of cardiovascular effects after atypical antipsychotic medication overdose. Am J Emerg Med. 2009 Jun;27(5):607-616. doi: 10.1016/j.ajem.2008.04.020. 